УДК 159.09.07 316.454.3 37.043

DOI https://doi.org/10.26661/2310-4368/2021-4-10

\title{
ПСИХОЛОГІЧНІ ОСОБЛИВОСТІ ДІТЕЙ, ПОЗБАВЛЕНИХ БАТЬКІВСЬКОГО ПІКЛУВАННЯ
}

\author{
Синякова В. Б. \\ кандидат педагогічних наук, дочент, \\ докторант \\ Інститут психології імені Г.С. Костюка \\ Національної Академії педагогічних наук України \\ вул. Панківська, 2, Київ, Україна \\ orcid.org/0000-0002-9750-6942 \\ vsinyakova@ukr.net
}

\begin{abstract}
Ключові слова: сирітство, діти, позбавлені

батьківського піклування, психологічні особливості, сочіальне сирітство, соичіалізація.
\end{abstract}

Проблема соціальної адаптації дітей-сиріт і дітей, які залишилися без піклування батьків, є вкрай важливою та потребує ефективних заходів для іiі вирішення. Особливо актуальною вона стає під час переміщення дитини в прийомну сім'ю. У статті наведено результати психологічних обстежень, які доводять, що найбільша кількість проблем та відхилень від нормального становлення особистості у вихованців дитячого будинку спостерігається в емоційно-вольовій сфері. Це пов'язано з порушенням компетентності соціальної взаємодії, невпевненістю у собі та своїх силах, зниженням самоорганізованості та цілеспрямованості, що в результаті призводить до значного зниження здатності до соціалізації. Також автором зазначено, що у дітей, позбавлених батьківського піклування, відзначаються особливості внутрішньої позиції: слабка орієнтованість на майбутнє, збідненість емоційних проявів, спрощений зміст образу самого себе, знижене ставлення до себе, упередженість щодо дорослих, однолітків та предметного світу, імпульсивність поведінки, ситуативність мислення й поведінки. Ці особливості особистості дитини, виникаючи у ранньому віці, не зникають, а набувають нових якостей та посилюються надалі. Таким чином, отримані результати дозволили виявити особливості психологічного розвитку підлітків, які мають різний досвід життя в сім’і, та зробити висновок щодо їхнього взаємозв'язку з різними сферами особистості: а) мотиваційною - небажання мати іншу сім'ю, страх за своїх батьків, яких вони знайдуть, коли вийдуть з дитячого будинку; б) емоційною-висока тривожність, фрустрація, почуття провини, страх бути знедоленим, низьке прагнення до прийняття, негативне самоставлення, високий рівень агресивності, дратівливості та підозрілості; в) вольовою залежність, схильність до підпорядкування, наслідування, пасивності, слабкості та безпорадності, низький ступінь пізнавальної активності та прагнення до спілкування, високий рівень конфліктності, низький ступінь соціальної адекватності поведінки, невпевненість у собі; г) сферою ставлення до сім’ї - дисгармонійне уявлення про дитячобатьківські відносини, схильність до ідеалізації образу батьків, образу матері, потреба у прихильності до дорослого, в індивідуальній увазі, неадекватність уявлень про сімейні ролі та функції. 
PSYCHOLOGICAL FEATURES OF CHILDREN DEPRIVED OF PARENTAL CARE

\author{
Syniakova V. B. \\ Candidate of Pedagogical Sciences, Associate Professor, \\ Doctoral Student \\ G.S. Kostiuk Institute of Psychology \\ of the National Academy of Educational Sciences of Ukraine \\ Pankivska str., 2, Kyiv, Ukraine \\ orcid.org/0000-0002-9750-6942 \\ vsinyakova@ukr.net
}

Key words: orphanhood, children deprived of parental care, psychological features, social orphanhood, socialization.

\begin{abstract}
The problem of social adaptation of orphans and children left without parental care is extremely important and needs effective measures to address it. It becomes especially relevant when moving a child to a foster family. The article presents the results of psychological examinations, which prove that the largest number of problems and deviations from the normal development of personality in orphans is observed in the emotional and volitional sphere, this is due to impaired competence of social interaction, insecurity and selforganization, reduced self-organization and purposefulness, which in turn leads to a significant reduction in the ability to socialize. The author also noted that children deprived of parental care have features of inner position: weak focus on the future, impoverishment of emotional manifestations, simplistic self-image, low self-esteem, prejudice against adults, peers and the material world, impulsive behavior, situational thinking and behavior. These features of the child's personality, arising at an early age, do not disappear, but acquire a new quality and intensify further. Thus, the results revealed the peculiarities of the psychological development of adolescents who have different experiences of family life, and conclude that their relationship with different areas of personality: motivational - unwillingness to have another family, fear for their parents, which they will find when they leave the orphanage; emotional - high anxiety, frustration, guilt, fear of being deprived, low desire to accept, negative attitudes, high levels of aggression, irritability and suspicion; volitional dependence, tendency to subordination, information, passivity, weakness and helplessness, low degree of cognitive activity and desire to communicate, high level of conflict, low degree of social adequacy of behavior, self-doubt; attitude to the family - disharmonious idea of child-parent relationship, the tendency to idealize the image of parents, the image of the mother, the need for attachment to an adult, individual attention, the inadequacy of ideas about family roles and functions.
\end{abstract}

Постановка проблеми. Однією 3 найгостріших соціально-економічних та психолого-педагогічних проблем у нашій країні є проблема соціального сирітства - явища, коли діти залишаються без батьківського піклування за живих батьків. Поняття «сирітство» багатоаспектне. Тлумачний словник надає таке визначення: «Сирота - дитина чи неповнолітній, в якого померла мати чи обоє батьків. Сирітство - стан сироти: самотність» [2]. 3 педагогічного погляду, сирітство - негативне соціальне явище, що характеризує спосіб життя неповнолітніх дітей, які залишилися без піклування батьків. На думку Л.Я. Оліференко,
T.М. Шульги, сироти - це особлива соціально-демографічна група дітей від народження до 18 років, які залишилися без піклування батьків через соціально-економічні та моральні причини [4]. Діти, що залишилися без піклування батьків, а також діти, батьки яких позбавлені батьківських прав або перебувають в ув'язненні, становлять одну з основних категорій серед неблагополучних дітей, категорію «соціальних сиріт».

Основними причинами сирітства в Україні $\epsilon$ погіршення матеріального становища населення, його соціально-економічне розшарування, міжнаціональні конфлікти, поява біженців, урбанізація, 
кризовий стан систем освіти та виховання. Наслідки раннього «соціального» сирітства $\epsilon$ надзвичайно важкими: глибокі та часто незворотні впливи на здоров'я і психіку ще до офіційної констатації втрати сім'ї; аномальний внутрішньоутробний розвиток у процесі небажаної вагітності; негативний соціальний досвід. Усе вищезазначене погано впливає на майбутне життя дитини, яка позбавлена батьківського піклування. Психічний розвиток дітей, що позбавлені батьківського піклування, наразі є дуже гострою та актуальною проблемою, оскільки визначає їх подальшу соціалізацію в суспільстві. А своєчасна корекція негативних станів $є$ передумовою їхньої успішної життедіяльності.

Мета статті полягає у визначенні психологічних особливостей дітей, які позбавлені батьківського піклування.

Виклад основного матеріалу. Перебування дітей, позбавлених батьківського піклування, у дитячих закладах інтернатного типу (будинки дитини, дитячі будинки, школи-інтернати) найменше відповідає інтересам дітей та уповільнює процес їхньої соціалізації в суспільстві. Через відсутність батьківського кохання та турботи діти позбавляються можливості задовольняти повною мірою одразу цілий комплекс необхідних для нормального розвитку потреб, головними 3 яких $є$ потреба у коханні та почуття безпеки. Патогенним фактором у дітей, позбавлених батьківського піклування, $є$ комплекс соціальних, педагогічних і психологічних впливів у колишніх батьківських сім'ях. Для соціального сирітства типові бездоглядність та гіпоопіка.

Характерною $є$ і проблема жорстокого поводження: фізичне, сексуальне, емоційне насильство, внаслідок чого у дітей спостерігаються ознаки сенсорної та соціальної депривації, відставання у психічному розвитку, ознаки мозкової дисфункції з неврологічними розладами, енурезом, порушеннями пізнавальної діяльності, емоційною нестійкістю, схильністю до брехні. Але найпотужнішим патогенним і дезадаптуючим фактором є відсутність батьківської сім'ї з відповідною природою дитини, що формується організацією життя, з властивим тільки біологічній сім'ї рівнем спілкування $з$ рідними, особливо $з$ матір'ю. Відрив дитини від батьків сприяє розвитку так званих деприваційних психічних розладів, важкість яких визначається періодом відриву від матері. 3. Фрейд зазначає, що розлука з матір'ю змушує дитину гостро переживати свою безпорадність, викликає у неї повторну емоцію страху, внаслідок чого це переживання фіксується, входить у зв'язок із якимось зовнішнім об'єктом і перетворюється на фобію [4, с. 45-49].

У ранньому дитячому віці депривація призводить до порушень: відставання у загальному та мовному розвитку, недостатнього розвитку дрібної моторики і міміки, надалі виявляються й емоційні порушення у вигляді загальної загальмованості прояву почуттів, схильності до страхів та тривожних станів, поведінкових відхилень. Ці показники є характерними для соціального сирітства.

А. Адлер, А. Фройд, Дж. Боулбі, Р.А. Шпіц, Й. Лангмейєр, досліджуючи розвиток особистості дитини, позбавленої батьківського піклування, дійшли висновку, що іiі спілкування $є$ особливим і характеризується напруженістю, стриманістю та агресивністю [10, с. 123-156].

Л.М. Шипіцина зазначає, що сирітство шкодить психічному та соціальному розвитку дитини. Причини розладів фізичного і психічного здоров’я у дітей-сиріт різноманітні. Зазвичай діти, позбавлені батьківського піклування, перевантажені психопатологічною спадковістю, мова йде насамперед про розумову відсталість та шизофренію. У дітей, які перебувають в інтернатних установах, спостерігається не тільки відставання у розвитку чи недорозвинення особистісних новоутворень, а формування принципово інших механізмів, за допомогою яких дитина пристосовується до життя. Це відбувається внаслідок порушення емоційних і комунікативних зв'язків із матір'ю та родичами, а також через те, що життя в інтернатній установі не вимагає від дитини функцій, які вона виконує у сім’ї. У дітей-сиріт знижено загальний психічний тонус, порушено процеси саморегуляції, домінує знижений настрій. Вони тривожні та невпевнені у собі, знижено емоційно-пізнавальну взаємодію i, відповідно, інтелектуальний розвиток [10, с. 87].

Є.А. Мінкова визначає такі особливості емоційного розвитку дітей, позбавлених батьківського піклування: знижений фон настрою; бідна гама емоцій; схильність до зміни настроїв; одноманітність та стереотипність емоційних проявів; емоційна поверхневість, що згладжує негативні переживання та сприяє їх швидкому забуванню; неадекватність форм емоційного реагування на схвалення та зауваження; підвищена схильність до страхів, нестабільність в емоційних контактах тощо. Також виявлено однобічність, бідність мотиваційної сфери, гіпертрофовану потребу в спілкуванні з дорослими, агресивність, невміння та небажання визнати свою провину, дефекти довільної саморегуляції поведінки, що виражаються у невмінні самостійно планувати та контролювати свої дії [2, с. 237].

Як показують дослідження багатьох авторів, діти, позбавлені батьківського піклування, нерідко стають учасниками або жертвами злочинів, втрачають роботу, житло, мають труднощі зі створенням сім’ї, відчувають труднощі у вихованні своїх дітей, демонструють асоціальну 
поведінку, виявляють схильність до суїциду тощо [16, с. 89].

Діти, що залишилися без батьківського піклування, мають особливий статус, який обумовлений соціальною ситуацією розвитку. Дитина перебуває в системі вимушених контактів, а це розмиває межі особистісного простору і значно ускладнює відновлення іiі психоемоційного ресурсу. Перебування дитини в дитячому будинку передбачає чітке дотримання одноманітних соціально-рольових позицій. Це своєю чергою значно ускладнює прояви індивідуальності та вільного самовираження [1, с. 12-15].

Досліджуючи Я-концепцію підлітків, що позбавлені батьківського піклування, А.М. Прихожан та Н.Н. Толстих дійшли таких висновків: підліткам характерна обмеженість самопрезентаційних навичок, що свідчить про бідність особистісних проявів, відсутність пріоритетних цінностей, вузькість інтересів, стійку негативну самооцінку, низьку мотивацію до саморозвитку, пріоритетність суспільної думки над власними уявленнями про себе [4, с. 89]. Отже, діти позбавлені батьківського піклування, мають певні психологічні особливості. Детальніше їх розглянуто у табл. 1 .

Таким чином, отримані результати дозволили виявити особливості психологічного розвитку підлітків, які мають різний досвід проживання в сім'ї, і зробити висновок щодо їх взаємозв'язку з різними сферами особистості: а) мотиваційною небажання мати іншу сім'ю, страх за своїх батьків, яких вони знайдуть, коли вийдуть 3 дитячого будинку; б) емоиійною - висока тривожність, фрустрація, почуття провини, страх бути знедоленим, низьке прагнення до прийняття, негативне самоставлення, високий рівень агресивності, дратівливості та підозрілості; в) вольовою - залежність, схильність до підпорядкування, наслідування, пасивності, слабкості та безпорадності, низький ступінь пізнавальної активності та прагнення до спілкування, високий рівень конфліктності, низький ступінь соціальної адекватності поведінки, невпевненість у собі; г) сферою ставлення до сім $\dddot{\imath}$ - дисгармонійне уявлення про дитячо-батьківські відносини, схильність до ідеалізації образу батьків, образу матері, потреба у прихильності до дорослого, в індивідуальній увазі, неадекватність уявлень про сімейні ролі та функції [3, с. 23-26].

Отже, формулюючи особливості дітей, що залишилися без піклування батьків, можна зробити такі висновки:

1. Недостатній інтелектуальний розвиток дитини може виражатися в ослабленні чи несформованості, нерозвиненості пізнавальних процесів, нестійкості уваги, слабкій пам'яті, слаборозвиненому мисленні (наочно-образному, абстрактному, логічному, вербальному), низькій ерудиції тощо. Причини низького інтелектуального розвитку можуть бути різні: від порушення нормальної роботи мозку до відсутності нормального освітньо-виховного середовища (педагогічна занедбаність). Відсутність належної уваги до інтелектуального розвитку дитини може призвести до серйозного відставання у навчанні.

Таблиця 1

Специфіка психічного розвитку дітей, позбавлених батьківського піклування

\begin{tabular}{|c|c|c|}
\hline \multirow{2}{*}{ Параметри } & \multicolumn{2}{|c|}{ Характеристики психічного розвитку } \\
\hline & Діти, позбавлені батьківського піклування & Діти, які виховуються в сім'ї \\
\hline Інтелект & $\begin{array}{l}\text { - ситуативність, наочність мислення; } \\
\text { - класифікаційне мислення [13]. }\end{array}$ & $\begin{array}{l}\text { - образний характер мислення, наявність } \\
\text { ідеального плану; } \\
\text { - творче мислення. }\end{array}$ \\
\hline Мотивація & $\begin{array}{l}\text { - вузькість та бідність змісту мотивів; } \\
\text { - прив’язаність до ситуації. }\end{array}$ & $\begin{array}{l}\text { - змістовність мотивів; } \\
\text { - вільність від ситуації [16]. } \\
\end{array}$ \\
\hline Довільність & $\begin{array}{l}\text { Орієнтація на зовнішній контроль, звичка до } \\
\text { постійного контролю. }\end{array}$ & $\begin{array}{l}\text { Орієнтація на самоконтроль, довільна са- } \\
\text { морегуляція. }\end{array}$ \\
\hline $\begin{array}{l}\text { Часова } \\
\text { трансперспектива }\end{array}$ & $\begin{array}{l}\text { Орієнтація на теперішній час, звужена пер- } \\
\text { спектива минулого та майбутнього. }\end{array}$ & $\begin{array}{l}\text { Змістовна перспектива минулого та май- } \\
\text { бутнього [9]. }\end{array}$ \\
\hline «Я-концепція» & $\begin{array}{l}\text { Неприйняття себе, недовіра до себе, орієнта- } \\
\text { ція у самооцінці на думку навколишніх, по- } \\
\text { чуття «МИ» }[15] .\end{array}$ & $\begin{array}{l}\text { Прийняття себе, довіра до себе, орієнта- } \\
\text { ція у самооцінці на власні критерії, по- } \\
\text { чуття «Я». }\end{array}$ \\
\hline Ідентичність & Невизначена. & Визначена. \\
\hline $\begin{array}{l}\text { Гендерна } \\
\text { ідентичність }\end{array}$ & Бідність, схематичність. & Адаптивність до соціального контексту. \\
\hline Спілкування & $\begin{array}{l}\text { Недовіра до людей, залежність, деструктивна } \\
\text { агресія у вирішенні конфліктів [11]. }\end{array}$ & $\begin{array}{l}\text { Довіра до людей, автономність, диферен- } \\
\text { ційованість поведінки у конфлікті, кон- } \\
\text { структивні способи їх вирішення. }\end{array}$ \\
\hline
\end{tabular}


2. Спільна діяльність та спілкування дітей 3 однолітками. У грі діти менш уважні до дій і станів партнера, часто зовсім не помічають образи, прохання та навіть сльози однолітка. Перебуваючи поряд, грають порізно. Або всі грають з усіма, але спільні ігри носять переважно процесуальний характер; відсутня рольова взаємодія у грі; навіть включаючись у будь-який загальний сюжет, діти діють від себе, а не від імені рольового персонажа. За операційним складом (за чинними діями) така діяльність дуже нагадує рольову гру, але за суб'єктивним, психологічним, змістом істотно відрізняється від неї. Контакти у грі зводяться до конкретних звернень та зауважень щодо дій однолітка (дай, дивись, посунься тощо).

3. Проблема статевої ідентифікації вихованців інтернатних установ. Стереотипи жіночої та чоловічої поведінки входять у самосвідомість через досвід спілкування й ідентифікацію з представниками своєї статі. У дитячих будинках діти ізольовані від цих орієнтацій. Дошкільнята вже добре знають про свою приналежність до статі, прагнуть до самоствердження себе як хлопчика чи дівчинки, в цьому вони мало відрізняються від дітей, які виховуються у сім'ї. Проте якісно статева ідентифікація має суттєві відмінності. Якщо діти в ній ідентифікуються зі своїми батьками, 3 близькими родичами й ровесниками, то діти, позбавлені батьківського піклування, ідентифікуються насамперед зі своїми однолітками.

4. Проблеми морального розвитку особистості вихованців. Проблеми морального розвитку починаються 3 молодшого шкільного віку і виявляються найчастіше у крадіжках, безвідповідальності, придушенні та скривдженні слабших, у зниженні емпатії, здатності до співчуття, співпереживання та загалом у недостатньому розумінні чи неприйнятті моральних норм, правил й обмежень.

5. Соціалізація дітей-сиріт. Під труднощами соціалізації фахівці розуміють комплекс труднощів дитини в процесі оволодіння тією чи іншою соціальною роллю. Освоюючи ці ролі, людина соціалізується, стає особистістю. Відсутність нормальних для звичайної дитини контактів (сім'я, друзі, сусіди тощо) призводить до того, що образ ролі створюється на основі суперечливої інформації, яку отримує дитина з різних джерел [5].

6. Проблеми емоційно-вольового розвитку вихованців. Найбільші труднощі та відхилення від нормального становлення особистості вихованців дитячих будинків відзначаються всіма дослідниками в емоційно-вольовій сфері. Це виявляється у порушенні соціальної взаємодії, невпевненості в собі, зниженні самоорганізованості, цілеспрямованості, недостатньому розвитку самостійності («сили особистості»), неадекватній самооцінці. Порушення такого роду проявляються найчастіше у підвищеній тривожності, емоційній напруженості, психічній втомі, емоційному стресі [7].

Висновки. Особливості життя у державній установі: напівзакритий характер, колективне виховання, коло спілкування, надмірний педагогічний вплив, обмеженість свободи вибору під час прийняття рішення, обмеженість трудових умінь, значно змінюють перебіг процесу соціалізації та адаптації в суспільстві дітей, позбавлених батьківського піклування. Також травматичною для цих дітей $є$ і будь-яка зміна звичного соціального оточення. Навіть усиновлення, передача в опікунську чи прийомну сім'ю зумовлює низку дезадаптивних реакцій. Отже, можна зазначити, що існує певна специфіка щодо соціалізації дітей, позбавлених батьківського піклування, - через зміну людей, які піклуються про дитину і до яких вона прив'язується, в дитини розвивається незацікавленість у соціальних взаєминах. Образ дорослого не асоціюється в неї з теплом та коханням.

Отже, діти-сироти і діти, позбавлені батьківського піклування, - це категорія дітей, яка має типологічні особистісні якості, обумовлені деприваційними, інституційними та педагогічними чинниками.

\section{ЛІТЕРАТУРА}

1. Артюшкіна Л.М., Поляничко А.О. Сирітство в Україні як соціально-педагогічна проблема (соціально-правовий аспект). Суми : СумДПУ, 2002. 268 с.

2. Бобылева И.А. Социальная адаптация выпускников интернатных учреждений : учебное пособие. Москва : Национальный фонд защиты детей от жестокого наказания, 2007. 543 с.

3. Волчек Н.А. Сиротский синдром. Социальная защита. 2007. № 9. 211 с.

4. Дорохова Т.С. Социальная адаптация детей, оставшихся без попечения родителей, к замещающей семье. Инновационная направленность обучения и воспитания в системе образования Екатеринбурга : материалы XVII городских педагогических чтений / под общ. ред. А.А. Симоновой, Н.А. Лопатюк. Екатеринбург : МБУ ИМЦ «Екатеринбургский дом учителя», 2011. 77 с.

5. Зубкова Т.С. Организация и содержание работы по социальной защите женщин, детей и семьи : учебное пособие. 2-е изд., стер. Москва : Академия, 2004. 224 с.

6. Карпенко О.Г. Сімейні форми утримання та виховання сиріт і підлітків, позбавлених батьківського піклування: проблеми правового регулювання. Право Украӥни. 2001. № 3. С. 28-39. 
7. Кондратьев М.Ю. Социальная психология закрытых образовательных учреждений. СанктПетербург, 2005. 346 с.

8. Лактионова Г.М., Шимиленко Е.С. Инновационные формы опеки детей: международный и национальный опыт. Киев : Науковий світ, 2001. 61 с.

9. Медико-психологічні та соціальні проблеми сиріт / під ред. М.М. Корєнєва, І.С. Лебець, Р.О. Моісеєнко. Київ : Науковий світ, 2003. 239 с.

10. Морозова Е.И. Проблемные дети и дети-сироты: Советы воспитателям и опекунам. 2-е изд., стереотип. Москва : Издательство НЦ ЭНАС, 2005. 56 с.

11. Пєша І.В. Соціальний захист сиріт і підлітків, позбавлених батьківського піклування (проблеми реформування). Київ : Логос, 2000. 87 с.

12. Прихожан А.М., Толстых Н.Н.Психология сиротства. Научный контекст, история, экспериментальное исследование проблемы. Москва : Прогресс,1990. 233 с.

13. Психология сиротства : тексты лекций / Е.А. Лупекина. Гомель : ГГУ им. Ф. Скорины, 2009. 151 с.

14. Одинцова А.Н., Шамахова Н.Н. Детский дом семейного типа / под ред. А.А. Коробейниковой. Вологда : ВИРО, 2010. 112 c.

15. Орсаг Ю.В. Проектирование содержания воспитания детей-сирот и детей, оставшихся без попечения родителей, в период их социально-профессиональной адаптации : дисс. ... канд. пед. наук. Вологда, 2007. 230 c.

16. Шипицына Л.М. Психология детей-сирот : учебное пособие. Санкт-Петербург : Издательство СПбУ, 2005. $628 \mathrm{c.}$

\section{REFERENCES}

1. Artyushkina, L.M., Polyanichko, A.O. (2002) Syritstvo v Ukrajini jak socialjno-pedaghoghichna problema (socialjno-pravovyj aspekt). [Orphanage in Ukraine as a social and pedagogical problem (social and legal aspect)]. Sumi : SumDPU. [in Ukrainian]

2. Bobyleva, I.A. (2007) Socyaljnaja adaptacyja vipusknykov ynternatnikh uchrezhdenyj [Social adaptation of boarding school graduates: Textbook] Moscow : National Fund for the Protection of Children from Cruel Punishment. [in Russian]

3. Volchek, N.A. (2007) Syrotskyj syndrom [Orphan syndrome]. Social protection. [in Russian]

4. Dorokhova, T.S. (2011) Socyaljnaja adaptacyja detej, ostavshykhsja bez popechenyja rodytelej, k zameshhajushhej semj'e [Social adaptation of children without parental care to a foster family. Innovative orientation of teaching and upbringing in the education system of Yekaterinburg : materials of the XVII city pedagogical readings] / under total. ed. A.A. Simonova, N.A. Lopatyuk. Yekaterinburg : MBU IMC "Yekaterinburg Teacher's House"). [in Russian]

5. Zubkova, T.S. (2004) Orghanyzacyja y soderzhanye raboti po socyaljnoj zashhyte zhenshhyn, detej y semjy [Organization and content of work on social protection of women, children and families: textbook] / T.S. Zubkova, N.V. Timoshina. 2nd ed., M. : Academy. [in Russian]

6. Karpenko, O.G. (2001) Simejni formy utrymannja ta vykhovannja syrit i pidlitkiv, pozbavlenykh batjkivsjkogho pikluvannja: problemy pravovogho reghuljuvannja [Simeyni formations and changes in children and children, relieved of the father's culture: problems of legal regulation]. Law of Ukraine. (in Ukrainian)

7. Kondratyev, M.Yu. (2005) Socyaljnaja psykhologhyja zakritikh obrazovateljnikh uchrezhdenyj [Social psychology of closed educational institutions]. St. Petersburg. [in Russian]

8. Laktionova, G.M., Shimilenko, E.S. (2001) Ynnovacyonnie formi opeky detej: mezhdunarodnij y nacyonaljnij opit [Innovative forms of child care: international and national experience]. K. : Naukoviy svit. [in Ukrainian]

9. Korunova, M.M., Lebets, I.S., Moiseenko, R.O. (2003) Medyko-psykhologhichni ta socialjni problemy syrit [Medical-psychological and social problems of syrt]. K. : Naukoviy svit. (in Ukrainian)

10. Morozova, E.I. (2005) Problemnye deti i deti-siroty: Sovety vospitatelyam i opekunam [Problem children and orphans: Tips for educators and guardians], 2nd ed. Moscow : Ed. NTs ENAS. [in Russian]

11. Pusha, I.V. (2000) Socialjnyj zakhyst syrit ta pidlitkiv, pozbavlenykh batjkivsjkogho pikluvannja (problemy reformuvannja). Kiev: Logos. [in Ukrainian]

12. Parishioners, A.M., Tolstykh, N.N. (2020) Psikhologiya sirotstva: Nauchnyy kontekst, istoriya, eksperimental'noe issledovanie problemy [Psychology of orphanhood: Scientific context, history, experimental study of the problem]. Moscow. [in Russian]

13. Lupekina, E.A. (2017) Psikhologiya sirotstva: teksty lektsiy po distsipline po vyboru dlya studentov spetsial'nosti [Psychology of orphanhood: texts of lectures on the discipline of choice for students of the specialty "Psychology"]. Gomel. [in Russian] 
14. Odintsova, A.N., Shamakhova, N.N. (2010) Detskiy dom semeynogo tipa [Family-type orphanage]. Vologda : VIRO. [in Russian]

15. Orsag, Yu.V. (2007) Proektirovanie soderzhaniya vospitaniya detey-sirot i detey, ostavshikhsya bez popecheniya roditeley, v period ikh sotsial'no-professional'noy adaptatsii : diss. k. ped. $\mathrm{n}$ [Designing the content of the upbringing of orphans and children left without parental care during the period of their social and professional adaptation : diss. Candidate of Pedagogical Sciences]. Vologda. [in Russian]

16. Shipitsyna, L.M. (2005) Psikhologiya detey-sirot : uchebnoe posobie [Psychology of orphans: textbook]. St. Petersburg: SPbU Publishing House. [in Russian] 